Brit. J. industr. Med., 1953, 10, 1.

\title{
THE INFLUENCE OF HORMONES ON THE DEVELOPMENT OF SILICOTIC NODULES PRODUCED BY INTRAPERITONEAL INJECTION OF QUARTZ
}

BY

ERICH SCHILLER

From the Department of Pneumoconiosis Research, "Rheinpreussen", Homberg (Niederrhein), Germany

(RECEIVED FOR PUBLICATION JULY 6, 1952)

In a previous paper (Schiller, 1951c) I put forward the view that the tissue reaction to silica was not a specific one. It is well known that cells give a common response to different types of injury (cf. Selye, 1951). It is improbable, therefore, that a particular pathogenic agent will produce an entirely new type of reaction. It is more probable that similar reactions will be produced by different agents. It is possible that the massive fibrosis found in the late stages of several types of pneumoconiosis is an example of this. By some authors (Giese, 1931 ; Wätjen, 1936; di Biasi, 1951) the process is believed to be due to silica, whereas, principally in South Wales, it is believed to be a modified type of tuberculosis (Husten, 1931; Gough, 1949, 1952 ; Gough, James, and Wentworth, 1949 ; Fletcher, Mann, Davies, Cochrane, Gilson, and Hugh-Jones, 1949 ; Fletcher and Gough, 1950 ; Heppleston, 1951 ; Fletcher, 1951). Both theories may well be correct.

The tissue reaction, whatever its cause, will also vary according to its immediate chemical environment, and in this paper I am dealing with the effect of certain endocrine substances on the formation of the silicotic nodule.

The inhibitory action of cortisone on proliferating connective tissue is well known. Its effect on wound healing has been studied by a great many authors (Ragan, Howes, Plotz, Meyer, and Blunt, 1949 ; Ragan, Howes, Plotz, Meyer, Blunt, and Lattes, 1950 ; Baker, 1950 ; Baker and Whitaker, 1950 ; Spain, Molomut, and Haber, 1950 ; Bangham, 1951) but their experiments only lasted a few days as did those of Taubenhaus and Amromin $(1949,1950)$. The most important finding seems to be that of Castor and Baker (1950), who maintained complete inhibition of hair growth in rats treated locally with a hog adrenal extract for about 160 days. After this hair began to grow again in spite of continued treatment. Microscopic examination of the skin showed that recovery had been almost complete. Magarey and Gough (1952) reported an inhibitory effect on intraperitoneal silicosis in the mouse, a depressant effect in the rat, and no effect in the guinea-pig. They gave a somewhat different dose of cortisone in relation to body weight, e.g. $125 \mathrm{mg} . / \mathrm{kg}$. in the mouse, $28.5 \mathrm{mg}$. $/ \mathrm{kg}$. in the rat, and only $16.5 \mathrm{mg} . / \mathrm{kg}$. in the guinea-pig. But in rabbits given only $8 \mathrm{mg}$. cortisone $/ \mathrm{kg}$. Magarey and Gough (1952) found a delay in the appearance of fibrosis. In using high doses of cortisone there is a risk of producing that atrophy of the adrenal cortex mentioned by Curran (1952) in his mice treated with $0.4 \mathrm{mg}$. cortisone daily.

For these reasons I decided to stimulate the adrenal cortex to produce cortisone itself, using oestrogens, insulin, and thyroxine.

The mode of action of oestrogens is rather doubtful. Selye (1940) reported an enlargement of the adrenal cortex of male rats given $300 \mu \mathrm{g}$. oestradiol daily for three weeks. Brand (1949) produced a doubling of the adrenal weight by $0.5 \mathrm{mg}$. stilboestrol in 10 days. Baker (1949) and Baker and Whitaker (1949) found that the impairment of hair growth by oestrogen was abolished after adrenalectomy. Ingle and Baker (1951), however, assume that the hormones of the adrenal cortex only play a supporting role. The hypoglycaemic reaction produced by high doses of oestrogen (Larizza and Ventura, 1951) must also be considered.

Insulin hypoglycaemia raises the A.C.T.H. level of human blood (Bartelheimer and Cabeza, 1942), the extract of which induces an adrenal enlargement in mice. Cuatrecasas (1949), Godlowski (1949), Kersley, Mandel, Jeffrey, Desmarais, and Bene (1950), and Kresbach and Stepantschitz (1951) tried 
insulin in rheumatoid arthritis with encouraging success. Henderson, Gray, Weinberg, Merrick, and Seneca (1950), who gave insulin together with cortisone, had less convincing results. Vogt (1950) attempted to explain this discrepancy by arguing that injected cortical hormones inhibit the pituitary response to stress :

" By giving the insulin along with the cortisone the physician defeats his own ends, because he prevents the very release of A.C.T.H. which presumably constitutes the beneficial action of insulin in rheumatoid arthritis."

Thyroxine induces a hypertrophy of the adrenal cortex (Durey, 1949; Tuchmann-Duplessis, 1951). Its distinct corticotrophic action is also mentioned by Selye and Stone (1950).

While high concentrations of desoxycorticosterone inhibit fibroblastic proliferation in tissue cultures (von Möllendorff, 1943 ; Meier, Gross, Desaulles, and Schär, 1952), low concentrations do not produce any effect (Meier and others, 1952) or accelerate the course of individual mitosis (von Möllendorff, 1942). In vivo Taubenhaus and

Amromin $(1949,1950)$ found an increased activity of fibroblasts.

Testosterone may restrict connective tissue formation by inhibition of anterior pituitary growth hormone (Taubenhaus and Amromin, 1950) as the simultaneous application of testosterone plus somatotrophin does not show this effect.

\section{General Methods}

Owing to the length of time required to obtain a reaction to silica by inhalation, the intraperitoneal technique was used. Albino mice, varying in weight from 18 to $24 \mathrm{~g}$., were injected intraperitoneally with a single dose of $10 \mathrm{mg}$. quartz suspended in $0.1 \mathrm{ml}$. saline solution. Quartz, 1 g., was sterilized by hot air and suspended in $10 \mathrm{ml}$. saline solution by an ultrasonic technique. Of the particles, $79 \cdot 55 \%$ were below $2 \mu$ measured by the Leitz phase-contrast equipment. The size and shape of the particles under the electron microscope are shown in Figs. 1 and 2.

The mice were divided into seven groups.

The mice in group I (152 male amd two female animals) remained untreated and served as controls.

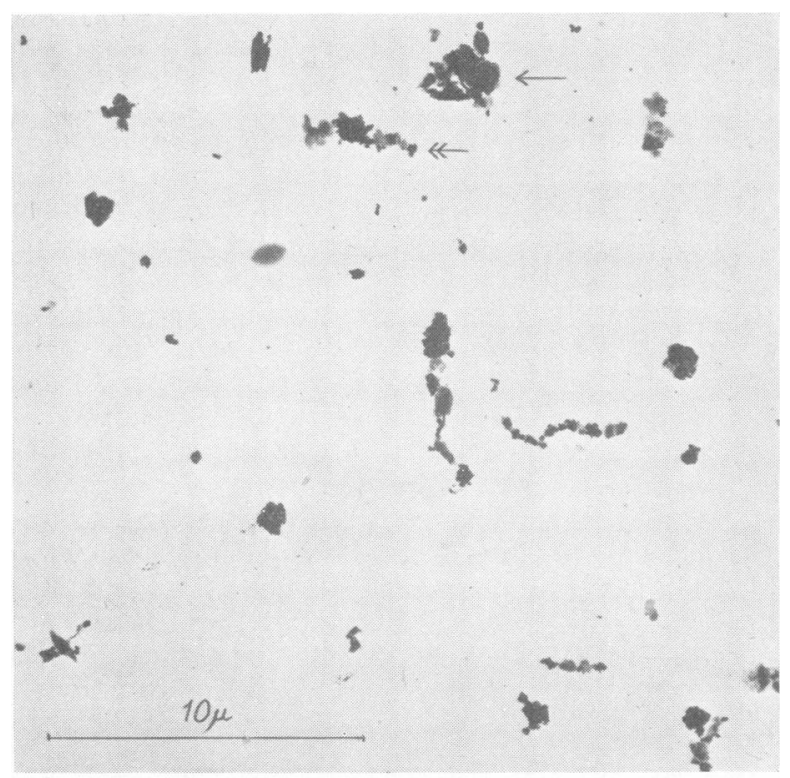

FIG. 1. - The quartz dust used in these experiments under the electron microscope (by courtesy of Dr. Walkenhorst, of Bochum).

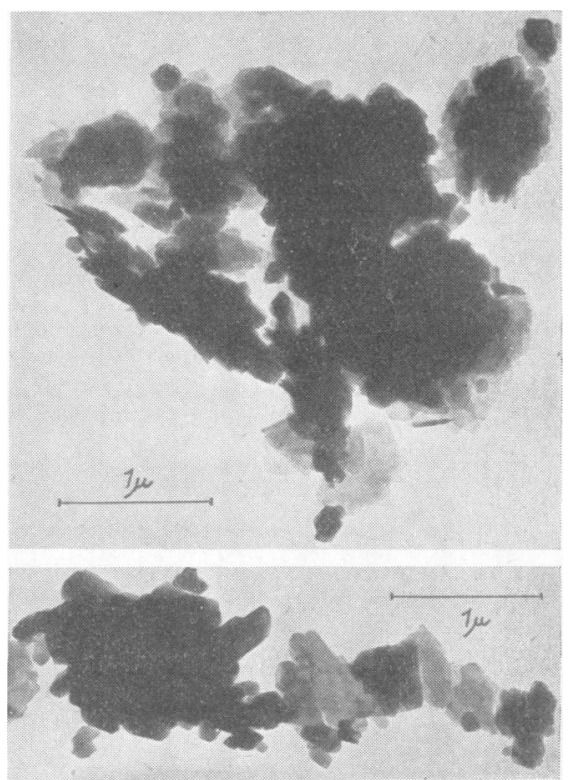

Fig. 2.-Details of the aggregates of particles indicated by arrows in Fig. 1 .

Of the particles, $79 \cdot 55 \%$ were below $2 u$ measured by the Leitz phase-contrast equipment. The size and shape of the particles under the electron microscope are shown in Figs. 1 and 2.

$$
\begin{array}{rr}
>20 \mu & 0.33 \% \\
10-20 \mu & 0.99 \% \\
4-10 \mu & 3.63 \% \\
2-4 \mu & 15.50 \% \\
<-2 \mu & 79.55 \% \\
100.00 \%
\end{array}
$$


TABLE

SUMMARY OF RESULTS AND DOSES GIVEN

\begin{tabular}{|c|c|c|c|c|c|c|}
\hline \multirow{2}{*}{ Group } & \multirow{2}{*}{ Hormone } & \multirow{2}{*}{$\begin{array}{l}\text { Period of } \\
\text { Application (Days } \\
\text { after Quartz } \\
\text { Injection) }\end{array}$} & \multirow{2}{*}{$\underset{(\mu \mathrm{g} .)}{\text { Single Dose }}$} & \multirow{2}{*}{ Total Dose } & \multicolumn{2}{|c|}{ Number of Animals } \\
\hline & & & & & Injected & Surviving* \\
\hline I & - & - & - & - & $\begin{array}{r}152 \text { males } \\
2 \text { females }\end{array}$ & $\begin{array}{r}100 \text { males } \\
1 \text { female }\end{array}$ \\
\hline II & Cortisone & $\begin{array}{c}1 \mathrm{st}-7 \mathrm{th} \\
8 \mathrm{th}-\text { death }\end{array}$ & $\begin{array}{l}200 \because \mathrm{g} \\
100 \mu \mathrm{g}\end{array}$ & $(3.6 \mathrm{mg})$ & 7 males & 0 \\
\hline III & Cyren B & $1 \mathrm{st}-39$ th & $0.25 \mu . \mathrm{g}$ & $9.75 \mu \mathrm{g}$ & 20 males & 7 \\
\hline \multirow{2}{*}{ IV } & \multirow{2}{*}{ Insulin } & $1 \mathrm{st}-29 \mathrm{th}$ & 0004 i.u. & 0.116 i.u. & 10 males & 5 \\
\hline & & $1 \mathrm{st}-59 \mathrm{th}$ & $0 . c 04$ i.u. & 0.236 i.u. & 10 males & 3 \\
\hline $\mathbf{V}$ & Thyroxine & $1 \mathrm{st}-29 \mathrm{th}$ & $0.25: 2 \mathrm{~g}$ & $7 \cdot 25 \mu \mathrm{g}$ & 10 males & 9 \\
\hline VI & D.O.C.A. & $1 \mathrm{st}-29 \mathrm{th}$ & $125 \mu \mathrm{g}$ & $3,625 \mu \mathrm{g}$ & 7 males & 4 \\
\hline
\end{tabular}

* All showed in varying degree the changes described.

The mice in group II (seven male animals) were injected subcutaneously with one daily dose of $200 \mu \mathrm{g}$. cortisone "ciba", beginning on the second day of the experiment. After seven days of such injections the dose was reduced to $100 \mu \mathrm{g}$. daily. As all these mice died within 18 days (cf. Magarey and Gough, 1952) and could give no reliable results, this experiment was repeated ( 10 male animals) with a dose of $20 \mu \mathrm{g}$. cortisone daily, the injections beginning on the twenty-first day after the intraperitoneal injection of silica. Two animals died on the twenty-fifth day after the beginning of the experiment and the surviving eight were killed on the thirtieth day.

The mice in group III (20 male animals) were injected subcutaneously with one daily dose of $0.25 \mu \mathrm{g}$. diethylstilboestrol-dipropionate (Cyren B Bayer), beginning on the second day of the experiment. The surviving seven were killed on the fortieth day after the beginning of the experiment.

The mice in group IV ( 20 male animals) were injected subcutaneously with one daily dose of 0.004 I.U. of "depot insulin Hoechst", beginning on the second day of the experiment. Five animals were killed on the thirtieth day after the beginning of the experiment, and three on the sixtieth day.

The mice in group V (10 male animals) were injected subcutaneously with one daily dose of $0.25 \mu \mathrm{g}$. thyroxine (" roche") beginning on the second day of the experiment. One animal died on the seventh day after the beginning of the experiment and the surviving nine were killed on the thirtieth day.

The mice in group VI (seven male animals) were injected subcutaneously with one daily dose of $125 \mu \mathrm{g}$. Doca ("cortiron schering"), beginning on the second day of the experiment. Three animals died on the seventh, fourteenth, and thirtieth day after the beginning of the experiment respectively, and the surviving four were killed on the thirtieth day.
The mice in group VII (seven male animals) were injected subcutaneously with one daily dose of $50 \mu \mathrm{g}$. testosterone propionate ("testoviron schering"), beginning on the second day of the experiment. Four animals died and the surviving three were killed on the thirtieth day after the beginning of the experiment.

Specimens of silicotic nodules, liver, spleen, kidneys, adrenals, hypophysis, gonads, thyroid, and lymph nodes were fixed in formaline or Carnoy's fluid, embedded in paraffin and sectioned at $6 \mu$. The slides were stained with haematoxyline-chromotrop 2 R, Azan, using Heidenhain's technique, and for reticulin Gömöri's technique. Frozen sections were stained for fat with Sudan III.

\section{Results}

Group I.-Well defined nodules became evident within one month. Their histological appearance varied according to their size and position. The largest granulomas had a necrotic centre surrounded by a zone of fibroblasts, histiocytes, lymphocytes, and leucocytes (Fig. 3). Both reticulin and collagenous fibres were present (Fig. 4). Some small nodules were hyalinized.

Group II.-Cortisone, though given only from the twenty-first day of the experiment, caused the lymphocytes to disintegrate. The resulting debris was found on the thirtieth day (Fig. 5). Only a fine reticulum was present (Fig. 6), but other organs, rich in hyaluronic acid, appeared swollen. No silica was found in the liver whereas Policard and Tuchmann-Duplessis (1951) found some in rats treated with A.C.T.H. All the silica had become adherent to the omentum, parietal peritoneum, and mesentery before the beginning of the cortisone treatment. 

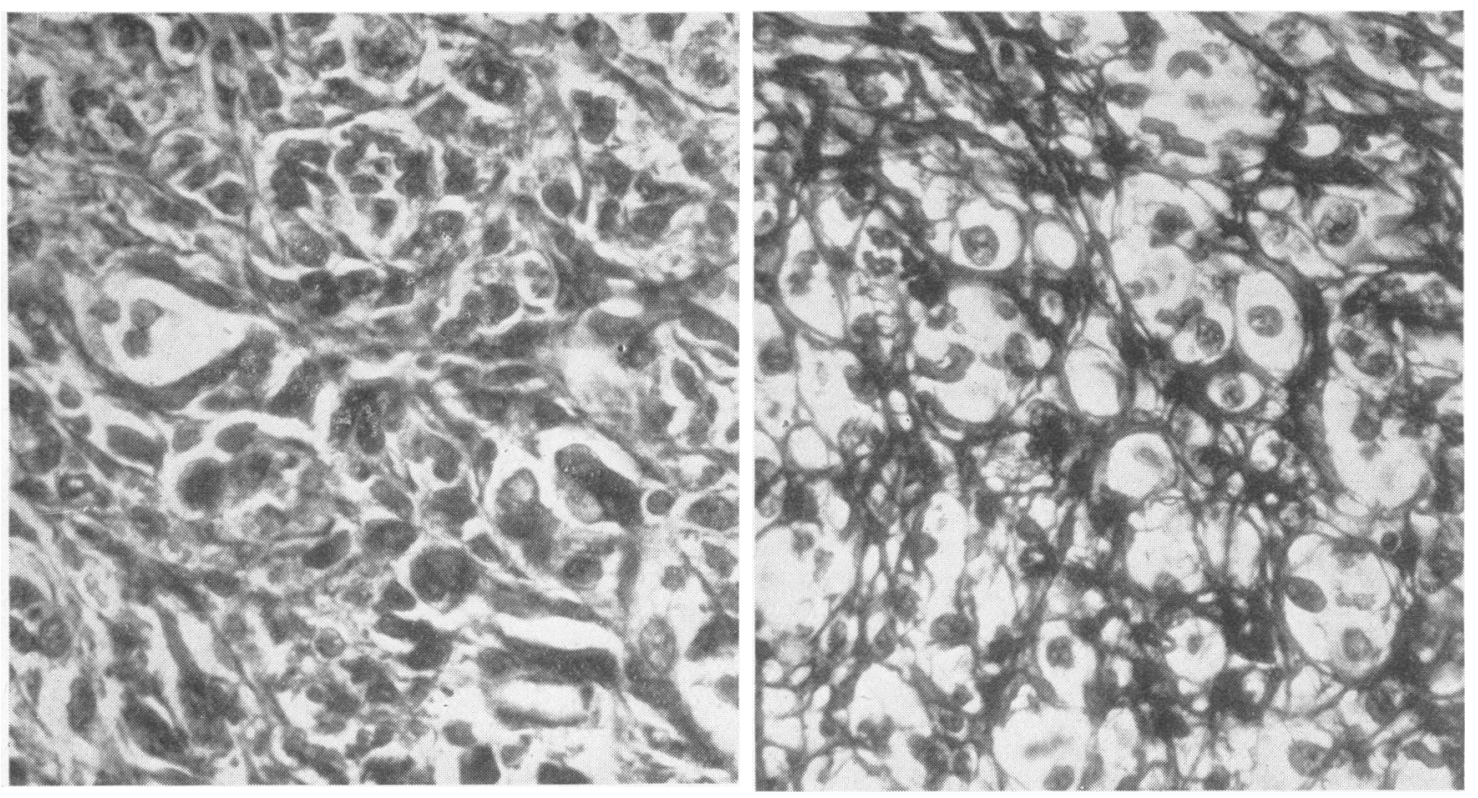

Figs. 3 and 4.-From group I (peritoneum parietale of animal No. 75/51 killed on the thirtieth day after the intraper itoneal injection of quartz).
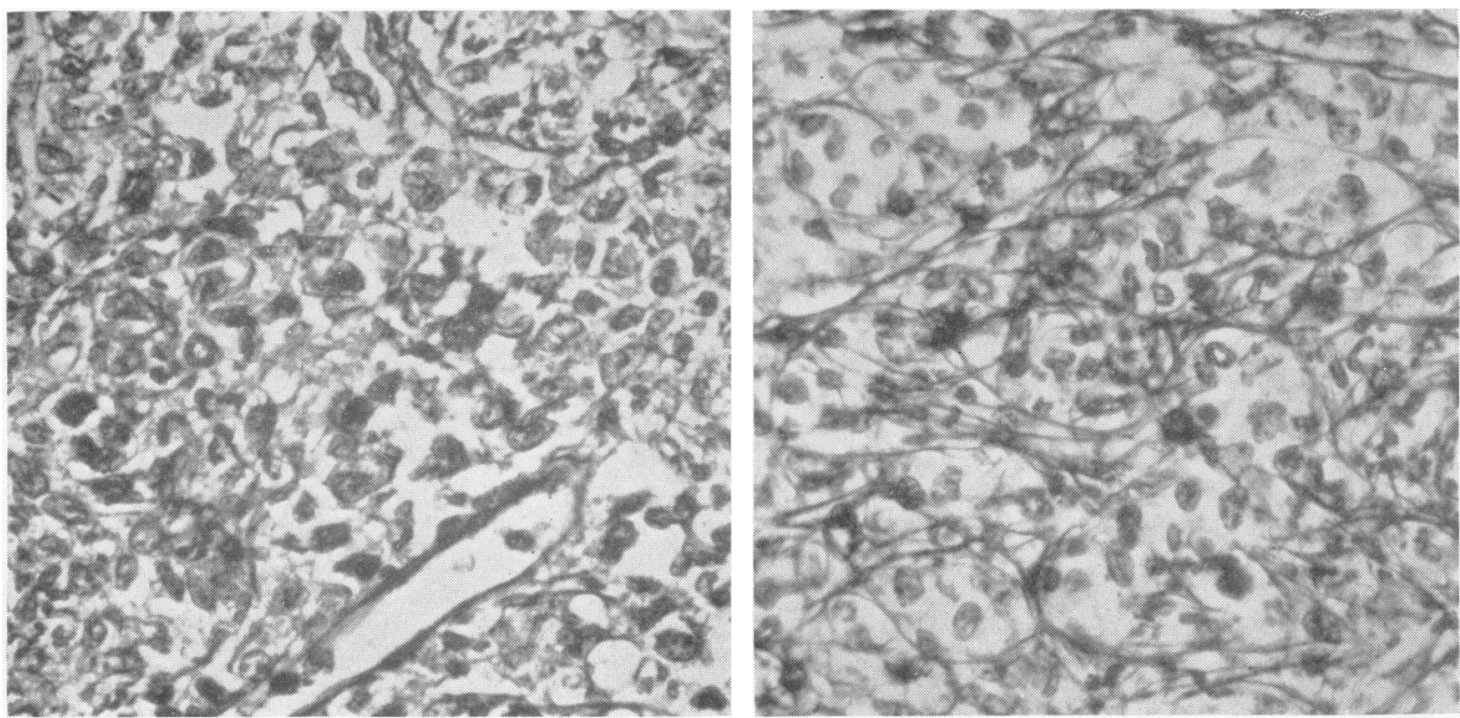

Figs. 5 and 6.-From group II (omentum of animal No. 65/51 killed on the thirtieth day).

Figs. 3 to 16.-Photomicrographs of tissue sections from quartz nodules of male animals from the different groups.

All specimens are fixed in Carnoy's fluid. The left series is stained for cells with haematoxylin-chromotrop $2 R(F i g s .3,5,11,13$, and 15) or azan (Figs. 7 and 9). All sections of the right series are stained for reticulin after Gömöri.

Photomicrographs are taken by the Leitz phase-contrast equipment showing phase contrast after Zernike. 

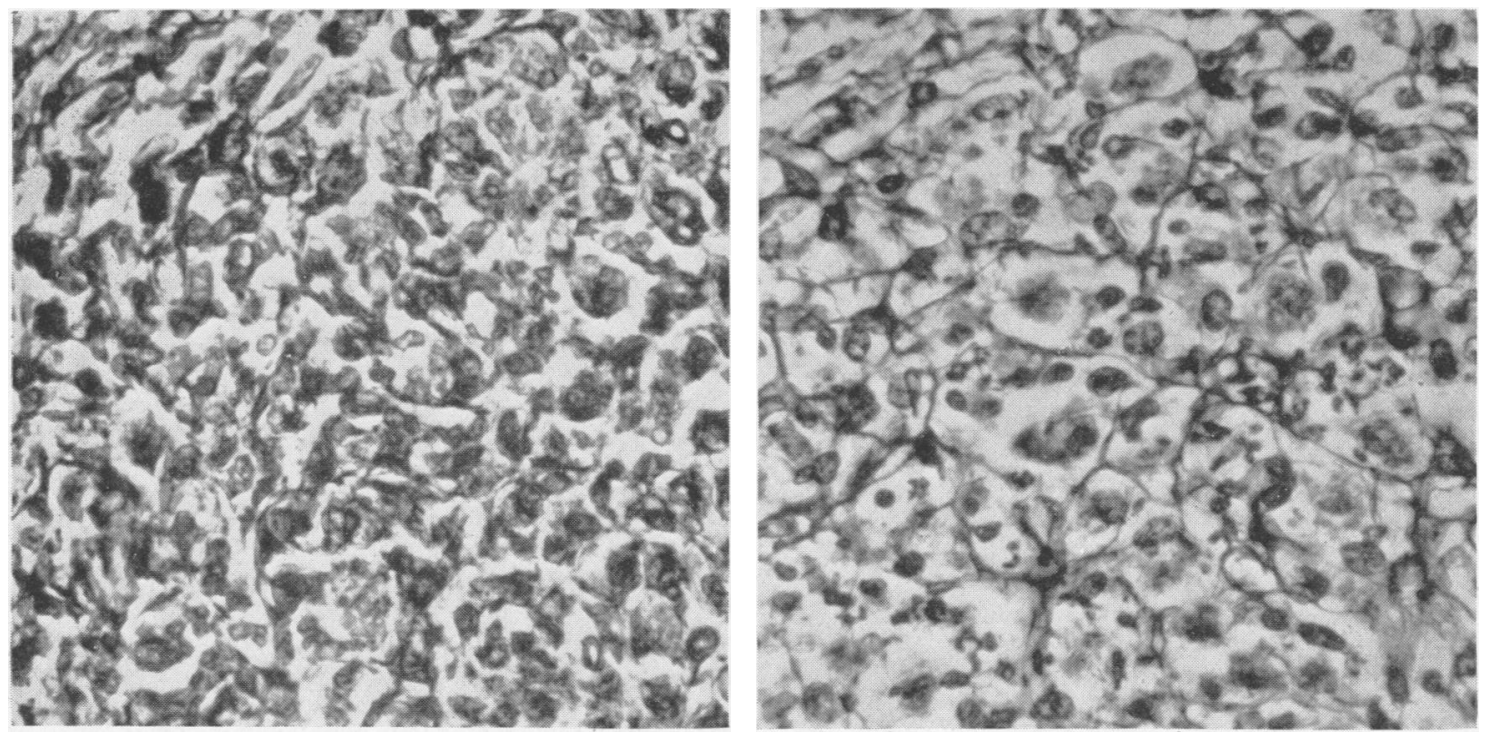

Figs. 7 and 8.-From group III (omentum of animal No. 106/51 and peritoneum near the ductus deferens of animal No. 107/51 respectively, both killed on the fortieth day).
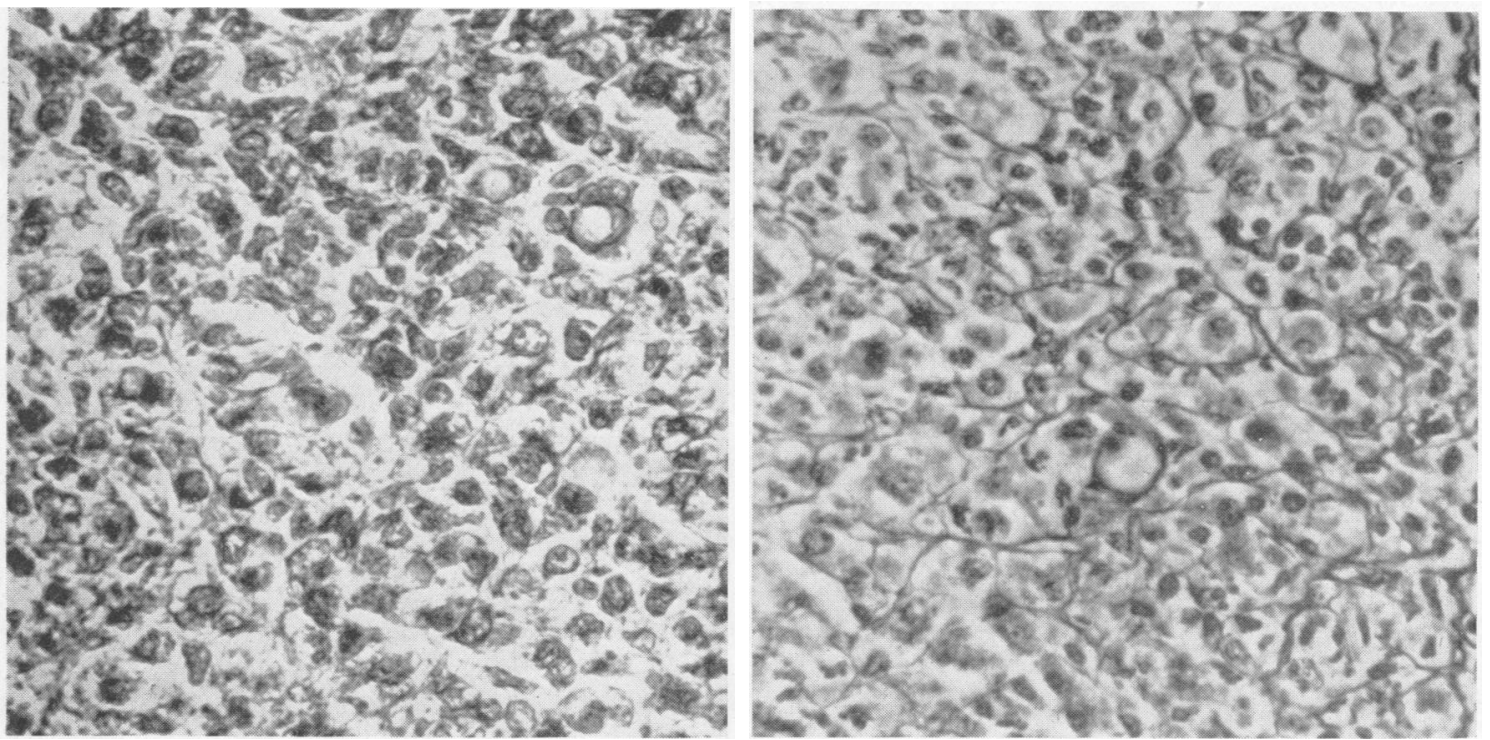

Figs. 9 and 10.-From group IV (feritoneum parietale of animal No. 150/51 killed on the sixtieth day).

Group III.-The mice treated with " cyren B" (Figs. 7 and 8) showed an effect similar to those in group II. The injection of hormone was started on the second day of the experiment in these mice, and some quartz was found in the lymph nodes and livers forming quartz nodules with a fine reticulum there.
Group IV.-Insulin retarded the formation of connective tissue so much that there was only a very fine network of reticulin on the sixtieth day (Figs. 9 and 10). As in the previous group some quartz nodules with a fine reticulum were found in the lymph nodes and livers. 

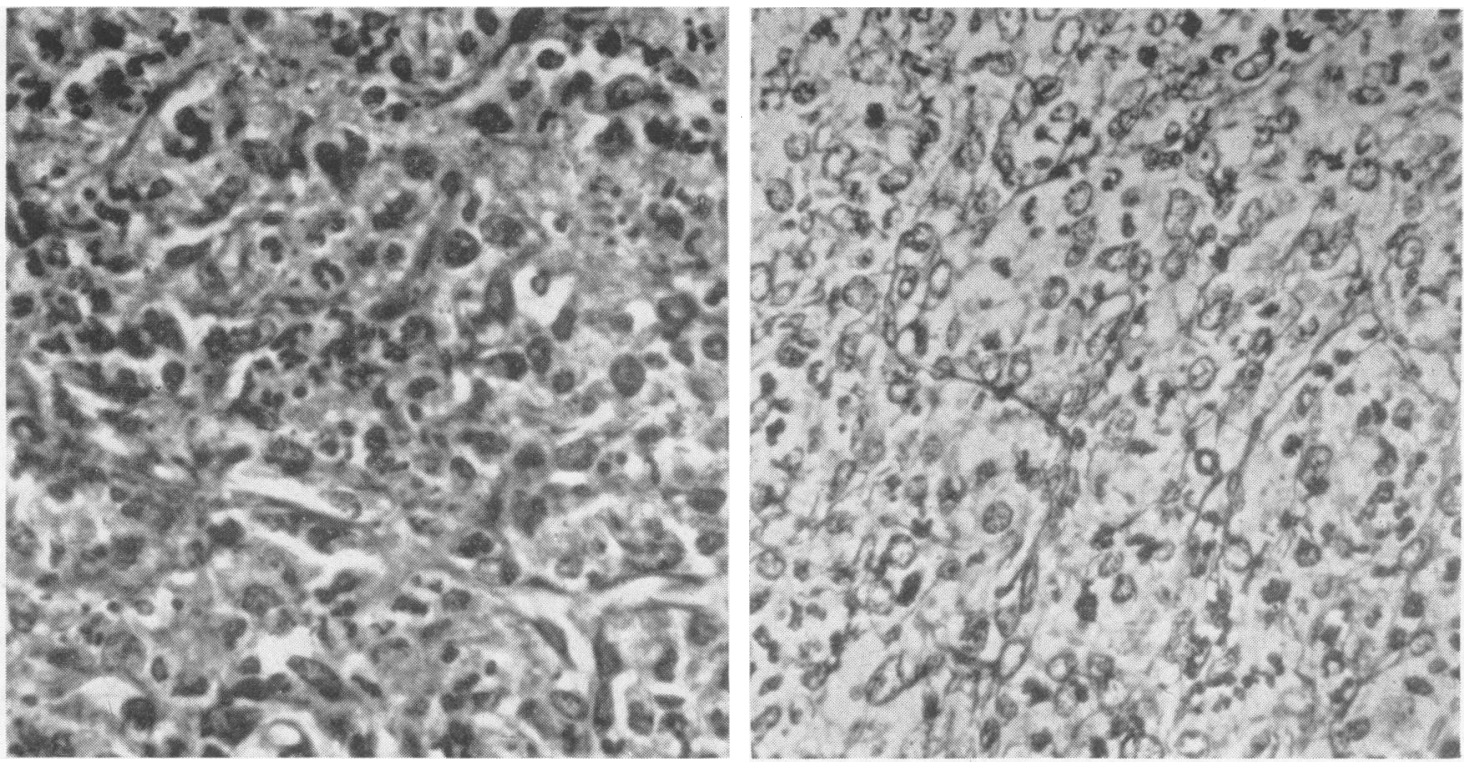

FIGs. 11 and 12.-from group V (animal No. 15/52 killed on the thirtieth day). Fig. 11 is taken from the peritoneum near the epididymis.
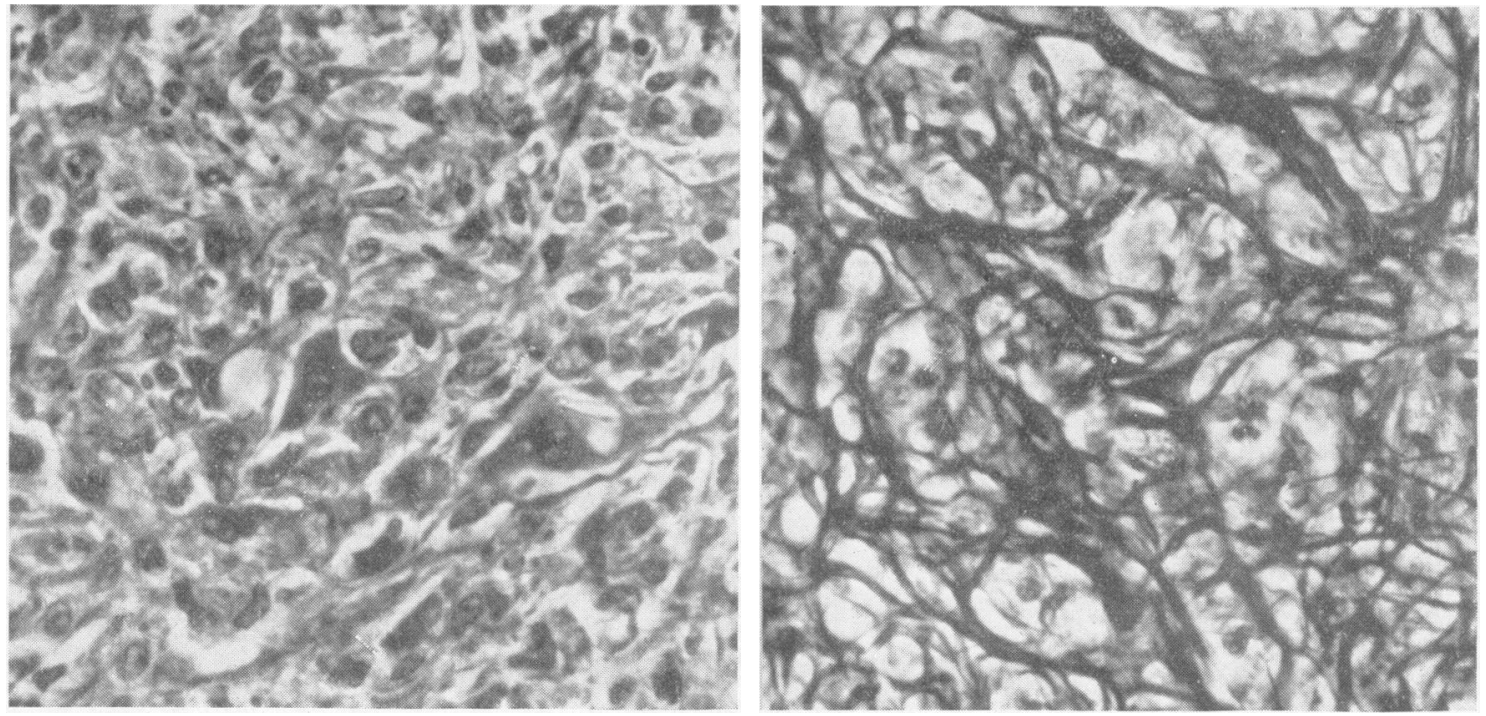

Figs. 13 and 14.-From group VI (omentum of animals No. 30/51 and 29/51 respectively, both killed on the thirtieth day).

Group V.-Thyroxine inhibited fibrosis (Figs. 11 and 12) in the same way as cortisone. Small quartz nodules were found in the lymph nodes of these mice.

Group VI.-Desoxycorticosterone acetate increased the fibroblastic proliferation (numerous mitoses) and the formation of collagen fibres (Figs. 13 and 14) and produced widespread infiltrations of lymphocytes, especially in the liver. Multinucleated giant cells appeared both in the silicotic nodules and in the liver. 

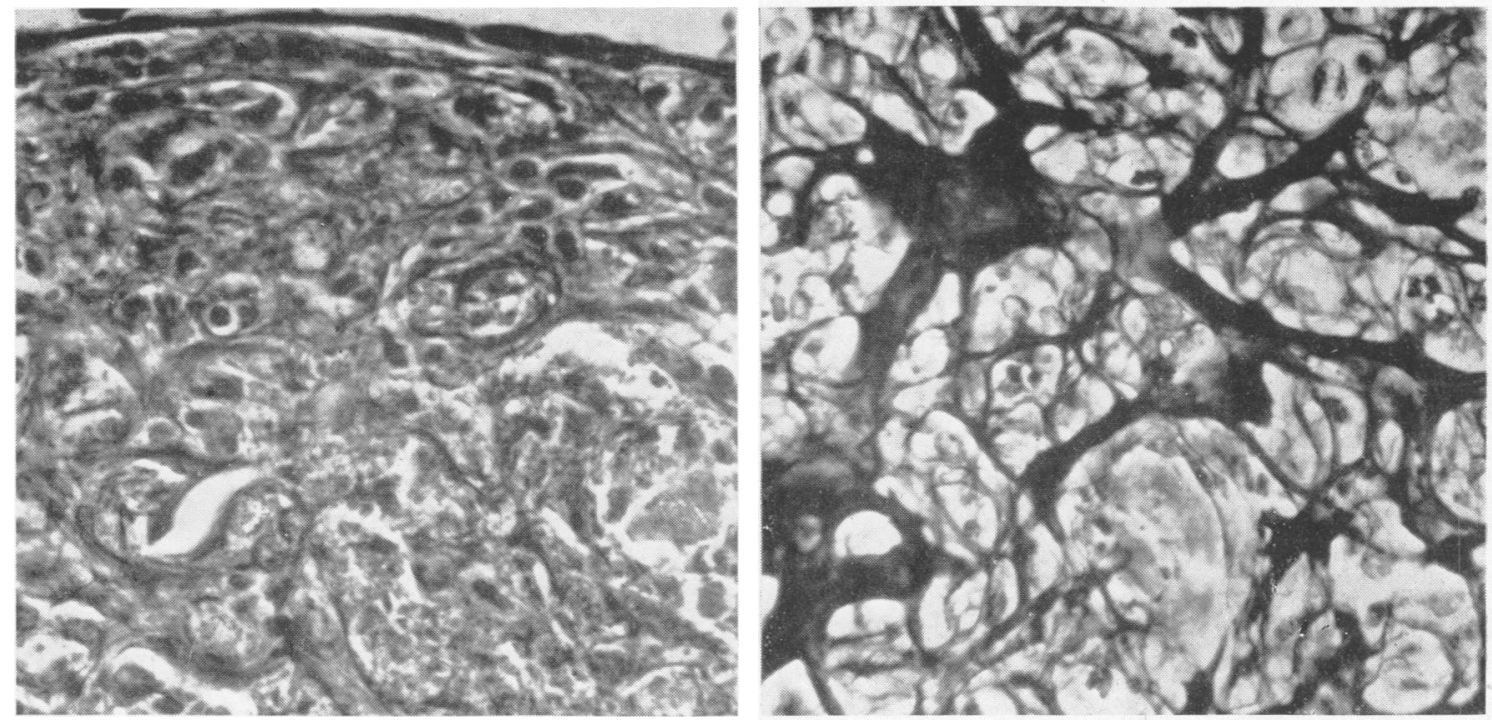

Figs. 15 and 16.-From group VII (surface of the adrenal of animal No. 35/51 and surface of the liver of animal No. 38/51 respectively, both killed on the thirtieth day).

Group VII.-Testoviron also increased the formation of connective tissue. In particular, the ground substance and the collagenous fibres were prominent (Fig. 16), while the fibroblasts appeared as small, spindle-shaped and pyknotic cells (Fig. 15).

The above results with the doses given are summarized in the table on page 3 . All surviving animals showed the reactions described but the degree of reaction will be reported in another paper.

\section{Discussion}

Cortisone, insulin, and thyroxine retarded the development of fibrosis in just the same way, affecting both the cellular constituents of the nodules and the ground substance with its derivatives. The essential constituent of the ground substance is hyaluronic acid, a muco-polysaccharide, the state of which may be controlled by enzymes secreted from the fibroblasts (Gersh and Catchpole, 1949). Thus the behaviour of this type of cells seems to be of special interest in the different groups of animals. The silicotic nodule conforms with other proliferating tissues in the scarcity of fibroblasts and ground substance after cortisone treatment, as described in wound healing by Ragan and others (1950).

The stress caused by silica may be mechanical or chemical. But Kettle's (1932) experiments, in which he coated the surface of the quartz with iron oxide, are generally accepted as ruling out the possibility of a simple mechanical action. An extremely fine amorphous silica (20 angstrom silica) has a high solubility, and is rapidly fatal to animals when injected in large amounts, while in smaller amounts its introduction in the lungs does not produce any fibrosis (King, 1947). This high fatality may be depressed by giving cortisone (Schiller, 1952). The microscopic examination of mice that died within 24 hours after the intraperitoneal injection of $10 \mathrm{mg}$. of such a fine silica, revealed the signs of severe stress, e.g. disintegration of thymus lymphocytes. A mixture of $9 \mathrm{mg}$. of the dust used in this paper plus $1 \mathrm{mg}$. of a 200 angstrom silica produced an effect on silicosis in the peritoneal cavity similar to that caused by the injection of cortisone (Schiller, 1952). These experiments suggest the possibility that pneumoconiosis may be a disease of adaptation. If this is so, we cannot expect cortisone, A.C.T.H., or any of the other beneficial hormones studied here to have a lasting effect in its treatment. It is, however, suggested that it might be of interest to investigate the hormonal constitution of miners.

\section{Summary}

The formation of silicotic granulomas after intraperitoneal injection of finely powdered quartz can be influenced by the regular injections of hormones. Cortisone, oestrogens, insulin, and thyroxine showed an inhibitory effect, while desoxycorticosterone 
acetate and testosterone propionate increased the formation of connective tissue.

\section{REFERENCES}

Baker, B. L. (1949), Anat, Rec., 103, 422. 1950). In Pituitary-Adrenal Function, ed. Christman, R. C., p. 88. Amer. Ass. Adv. Sci.

- and Whitaker, W. L. (1949). Amer. J. Physiol., 159, 118. (1950). Endocrinology, 46, 544

Bangham, A. D. (1951). Brit. J. exp. Path., 32, 77

Bartelheimer, H., and Cabeza, J. F. (1942). Klin. Wschr., 21, 630.

Biasi, W. di (1951). Beiträge zur Silikose-Forschung. Bericht über die medizinisch-wissenschaftliche Arbeitstagung über Silikose vom 18.-20 Oktober 1951 , p. 151

Brand, M. (1949). Arch. int. Pharmacodyn., 79, 298.

Castor, C. W., and Baker, B. L. (1950). Endocrinology, 47, 234.

Cuatrecasas, J. (1949). Sem. méd. (B. Aires), 56, 613.

Curran, R. C. (1952). Brit. J. exp. Path., 33, 82.

Curran, R. C. (1952). Brit. J. exp. Path., 33, 82.

Fletcher, C. M. (1951). Beiträge zur Silikose-Forschung. Bericht über die medizinisch-wissenschaftliche Arbeitstagung über Silikose vom 18.-20. Oktober 1951, p. 119.

—, and Gough, J. (1950). Brit. med. Bull., 7, 42.

Mann, K. J., Davies, J., Cochrane, A. L., Gilson, J. C., and Hugh-Jones, P. (1949). J. Fac. Radiol. (Lond.), 1, 40.

Gersh, I., and Catchpole, H. R. (1949). Amer. J. Anat., 85, 457.

Giese, W. (1931). Veröff. Gewerbe Konstit. path., Heft 28

Godlowski, Z. Z. (1949). Ann. rheum. Dis., 8, 285.

Godlowski, Z. Z. (1949). Ann. rheum. Dis., 8,

(1952). Patterns in Pneumoconiosis, 4th Conference of Mclntyre Res. Found. on Silicosis.

—, James, W. R. L., and Wentworth, J. E. (1949). J. Fac. Radiol. (Lond.), 1, 28.

Henderson, E., Gray, J. W., Weinberg, M. Merrick, E. Z., and Seneca, H. (1950). J. clin. Endocr., 10, 800.
Heppleston, A. G. (1951). Arch. industr. Hyg., 4, 270.

Husten, K. (1931). Veröf. Gewerbe. Konstit. path., Heft 29.

Ingle, D. J., and Baker, B. L. (1951). Endocrinology, 48, 764.

Kersley, G. D., Mandel, L., Jeffrey, M. R., Desmarais, M. H. L., and Bene, E. (1950)." Brit. med. J., 2, 855.

Kettle, E. H. (1932). J. Path. Bact., 35, 395.

King, E. J. (1947). Occup. Med., 4, 26.

King, E. J. (1947). Occup. Med., 4, 26. Wien. klin.Wschr., 63, 536

Kresbach, E., and Stepantschitz, G. (1951, Wien. klin. Wschr., 63,

Larizza, P., and Ventura, S. (1951). Folia endocr. (Pisa), 4, 65.

Magarey, F. R., and Gough, J. (1952). Brit. J. exp. Path., 33, 76.
Meier, R., Gross, F., Desaulles, P., and Schär, B. (1952). Bull. schweiz. Akad. med. Wiss., 8, 34

Möllendorff, W. von (1942). Z. Zellforsch., 32, 35.

Policard, A., and Tuchmann-Duplessis, H. (1951). C. R. Acad. Sci. (Paris), 232, 1888.

Ragan, C., Howes, E. L., Plotz, C. M., Meyer, K., and Blunt, J. W. (1949). Proc. Soc. exp. Biol. (N.Y.), 72, 718.

一

Schiller, E. (1951a). Anat. Anz., 98, Erg.-H., 122.

(1951b). Experientia (Basel),

(1951c). Beiträge zur Silikose-Forschung. Bericht iber die medizinisch-wissenschaftliche Arbeitstagung über Silikose vom 18.-20. Oktober 1951, p. 251.

(1952). Verh. anat. Ges., 50. In the press.

Selye, H. (1940). Canad. med. Ass. J., 42, 113.

—, 1951). Dtsch. med. Wschr., 76, 965, 1001. the adrenal cortex. Thomas, Springfield, Ill.

Spain, D. M., Molomut, N., and Haber, A. (1950). Science, 112, 335.

Taubenhaus, M., and Amromin, G. D. (1949). Endocrinology, 44,

_- 359 . (1950). J. Lab. clin. Med, 36, 7

Tuchmann-Duplessis, H. (1951). Presse méd., 59, 1749.

Vogt, M. (1950). Brit. med. J., 2, 1242.

Wätjen, J. (1936). Nova Acta Leop. Carol., 3, 475. 